\title{
7. 立体供給型手術部モデルにおける各種動線の機能評価
}

\section{名城大学都市情報学部人間情報処理研究室}

酒井順哉

\section{1. 研究目的}

病院建筑における手術部モテルは、その時代 の建築技法やコンセプトとともに変革してきた が、従来から手術部モデルの評価については 様々な議論がなされてきた。

従来、手術部モデルの多くが中廊下型モデル で設計されていたが、人・清潔器材・污物類の 動線が交差する久点があったため、近年では、 院内感染防止を強化すべく清潔動線と不潔動線 を分離することを意識した回収廊下型モデルや 清潔ホール型モデルの建築設計が比較的多く採 用されるようになった。

回収廊下型モデルは、中廊下型モデルと人や 清潔器材の動線は変化ないが、使用潜み手術器 材や污物類などの搬出に必要な不潔動線を単独 にすることで、人や清潔器材との動線分離を図 ることが可能になった。

一方、清潔ホール型モデルでは、清潔器材の 動線分離が明確にされたものの、人と污物類の 動線分離は図られていない。

著者は、同規模の中廊下型、回収廊下型、清 潔ホール型の各手術部モデルの人的動線距離を シミュレーションによって計算した結果、清潔 ホール型においては手術室を定期的に巡回支援 する麻醉スーパーバイザーの動線や、清梁ホー ル内看落婦の動線がきわめて長くなることが分 かった。

以上のことから、著者は、人・清樑器材・污 物類の完全動線分離と人的動線距離の短㮁を実 現する方法として、立体供給型手術部モデルを 第 20 回日本病院設備学会において提呾した。

立体供給型モデルは、㓕菌コンテナや医療材 料などの清潔医療器材を保管した材料部とその 直上階に設計された回収廊下型手術部平面をべ 一スにバーチカルコンベアなどの自動搬送シス テムを用いて直接手術室に手術器材を供給する 新しいコンセプトの手術部モデルである。 今回、立体供給型手術部モデルによって手術室

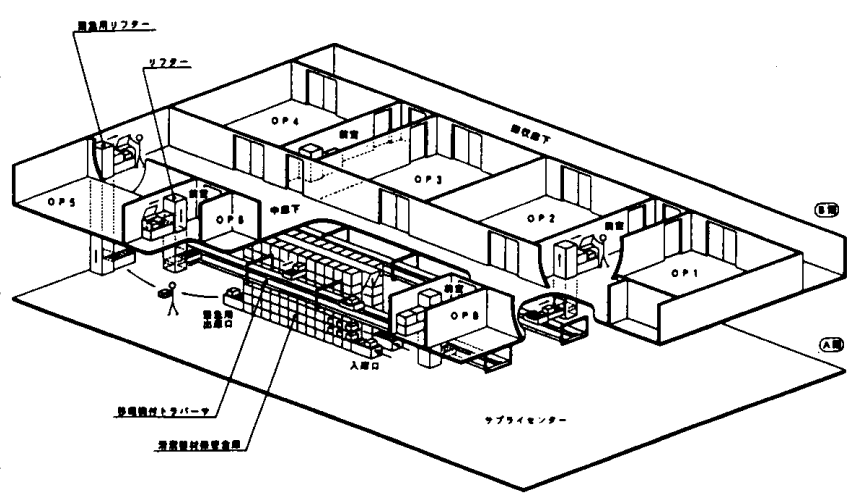

图 1，立体供給型手街部の設咶案 が運用されることを想定した時、患者・術者・ 麻酔スーパーバイザ・看讙婦などの人的動線が、 同一規模で設計された回収廊下型・清潔ホール 型モデルに比べてどの程度改善されるかをシミ ュレーションによって試みた。

\section{2. 功線の分析方法}

動線の分析には、回収廊下型、清潔ホール型、 立体供給型手術部モテルを用いた。なお、動線 の比較分析を容易にするため、手術室 $(6 \mathrm{~m} \times$ $6 \mathrm{~m})$ 、手術室廊下幅 $(3 \mathrm{~m})$ 、医療材料倉庫 $(10 \mathrm{~m} \times 6 \mathrm{~m})$ 、清潔ホール $(24 \mathrm{~m} \times 6 \mathrm{~m})$ 、前室 $(3 \mathrm{~m} \times 6 \mathrm{~m})$ など各種区画サイズを統一し、8 8 部 屋から構成される手術部モデルでシミュレーシ ヨンを行った。

今回、詳細に分析を行った動線は、医療材料 やコンテナなどの医療器材の供給を行う外回り 看護婦（場合により清潔ホール看護媂を含む） の動線距離と、麻酔スーパーバイザが麻醉監督 および支援に要する移動動線距離である。医療 味量の供給動線の分析には、各手術室の出入り 回数を単純に加算によって計算した単純加算シ ミュレーションと、手術の重賃度の高い手術室 ほど出入り回数が増加すると考えた重み付け加 算によるシミュレーションの 2 通りで行った。 重み值には重賃度の高い手術室から 8、4、2、 1 倍の 4 段階で計算した。 


\section{（14）医器学 Vol.66, No.10 (1996)}

\section{3. 分析轺果}

回収廊下型、清樑ホール型、立体供給型手術 部モデルにおける医療材料供給動線の単純加算 分析結果を図 2 に示す。この結果から動線距離 は、立体供給型く清潔ホール型く回収廊下型と なり、回収廊下型では立体供給型や清潔ホール 型の約 3 倍の動線になることが分かる。

一方、供給動線の重み付け加算分析では、重 みの少ない手術室の動線に大差ないが、回収廊 下型モデルの重症度の高い手術室では他の手術 部モデルの約 3 倍の動線となった（図 3 ）。また、 立体供給型モデルでは手術室での供給動線は一 定であるのに対し、清潔ホール型モデルでは両 端の手術室動線が約 2 倍となった。

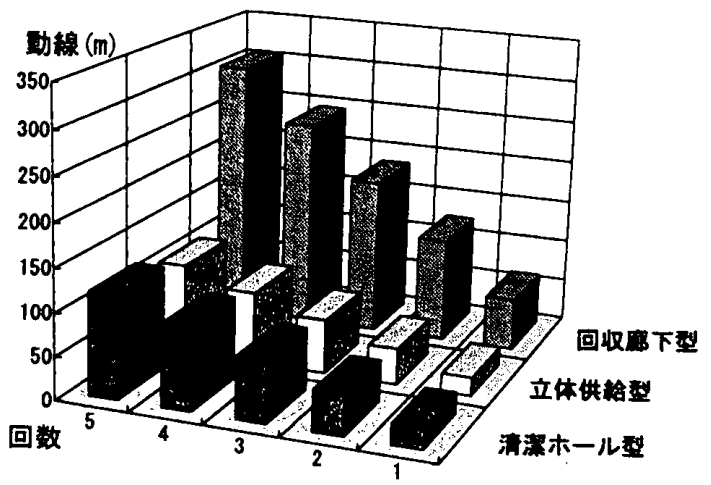

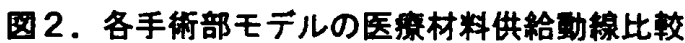

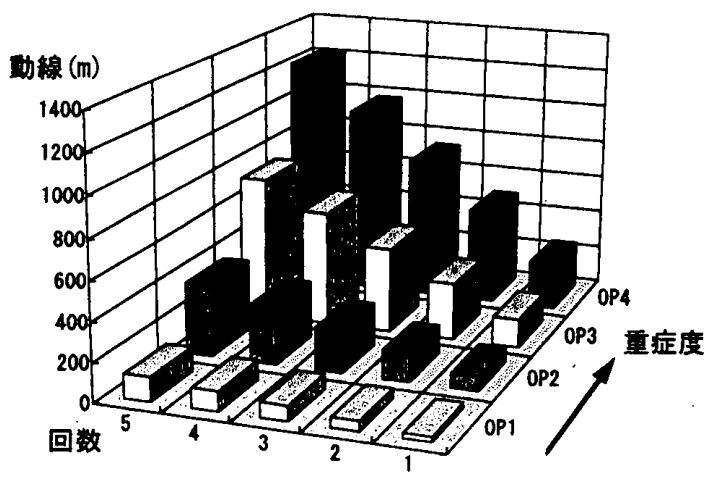

图 3.回収廊下型の医療材料供給勒㙞比较

立体供給、清墚ホール型の麻酔スーパーバイ ザの移動動線の分析結果を図 4 、図 5 に示す。 回収廊下型は立体供給型とほほ同様な分析結果 となり、どの手術室間でも麻酔スーパーバイザ の動線短絔に有効であることが分かる。一方、 図 5 のように清梁ホール型の麻酔スーパーバイ ザの移動動線は廊下特性から雄れた位直にある 手術室間の動線は約 3 倍と長くなることが分か った。

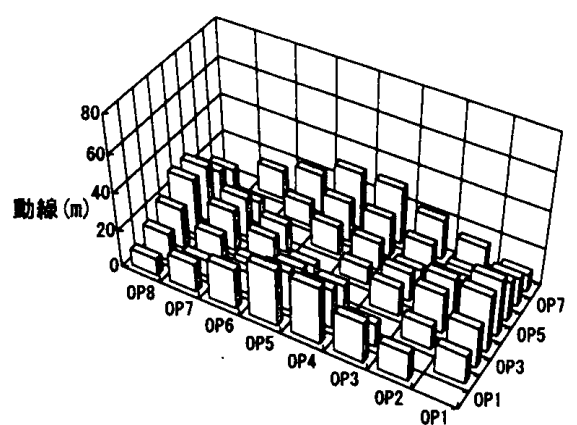

图 4．立体供站型モテルにおける麻略医峌楾

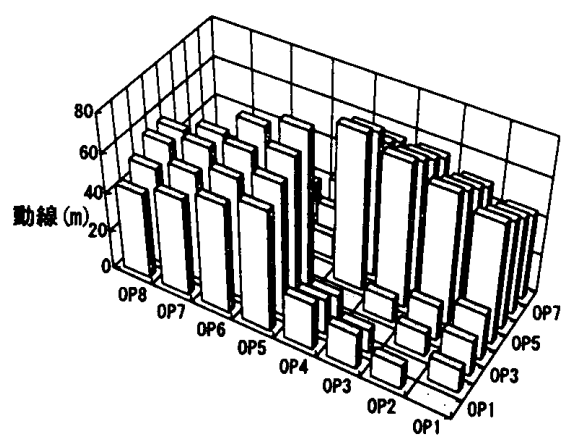

図 5.清潔ホール型モテルにおける麻醉医的楾

\section{4. 考裳}

分析結果から、医療材料の供給動線短縮には 清潔ホール型や立体供給型モデルが適するが、 麻酔スーパーバイザの移動動線短縮には回収廊 下型や立体供給型モデルが適することが分かっ た。医療材料の供給動線が短縮できることは、 手術中に䋈急に必要になった医療材料の供給を 短時間に供給できることを意味する。しかし、 㴒潔ホール型モデルの場合、医療材料の供給動 線の大部分が清潔ホール看護婦に集中するため、 過重労働や業務停滞を招く恐れがあり、運用面 での負荷分散のための配虑が必要となる。

一方、麻酔スーパーバイザの移動動線が短縮 できることは、手術患者の急変に伴う患者管理 を迅速に行えることを意味するぼかりでなく、 麻酔スーパーバイザの疲労軽减にも役立つ。

\section{5.まとぬ}

立体供給型モデルは、従来の手術部モデルに 比して、人・清潔器材・污物類の完全動線分嚾 と人的動線距離の短樎に有用であり、今後、搬 送装嘼等の設計仕様について検討することを予 定している。

\section{【参考文献】}

1)酒井順哉：各種情報・搬送機器を用いた新し い手術室設計の提案,病院設備, Vol.38(2), 176179、 1996. 